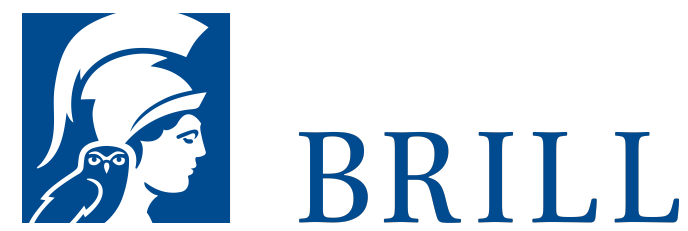

\section{Das Seiende und das göttliche Denken Hegels Auseinandersetzung mit der antiken Ersten Philosophie}

\section{Author: Klaus Düsing}

Die Nordrhein-Westfälische Akademie der Wissenschaften und der Künste ist eine Vereinigung der führenden Forscherinnen und Forscher des Landes. Sie wurde 1970 als Nachfolgeeinrichtung der Arbeitsgemeinschaft für Forschung des Landes Nordrhein-Westfalen gegründet. Die Akademie ist in drei wissenschaftliche Klassen für Geisteswissenschaften, für Naturwissenschaften und Medizin sowie für Ingenieur- und Wirtschaftswissenschaften und in eine Klasse der Künste gegliedert.

Mit Publikationen zu den wissenschaftlichen Vorträgen in den Klassensitzungen, zu öffentlichen Veranstaltungen und Symposien will die Akademie die Fach- und allgemeine Öffentlichkeit über die Arbeiten der Akademie und ihrer Forschungsstellen informieren.

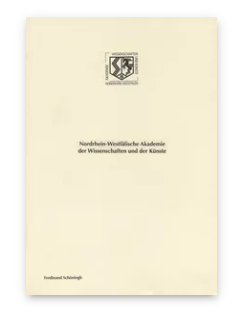

Pages: 36 Seiten

Language:

German

Subjects:

German

Idealism,

Philosophy

Publisher: Brill |

Schöningh

Series:

Nordrhein-

Westfälische

Akademie der

Wissenschaften und der Künste - Vorträge:

Geisteswissenschaften,

Volume: 423

E-Book (PDF)

Released online:

30 Dec 2019

ISBN: 978-3-

657-76903-2

List price

USD $\$ 24.00$

Paperback

Publication date:

18 Nov 2009

ISBN: 978-3-

5o6-76903-9

List price

USD $\$ 24.00$ 
For more information see brill.com

Order information: Order online at brill.com +44330 333 0049 | customerservices@brill.com Submission information: brill.com/authors

Titles published by Brill | Fink, Brill | mentis or Brill | Schöningh: +49(o)715413279216| brill@brocom.de 